\title{
FANCE Gene Mutation
}

National Cancer Institute

\section{Source}

National Cancer Institute. FANCE Gene Mutation. NCI Thesaurus. Code C131791.

A change in the nucleotide sequence of the FANCE gene. 